\title{
Uitverkiesing en etiek
}

\author{
P.F. Theron
}

Departement Sistematiese Teologie en Ekklesiologie

Universiteit van Stellenbosch

STELLENBOSCH

E-pos: pft@sun.ac.za

\begin{abstract}
Election and ethics

The doctrine of election is of fundamental importance in the Reformed tradition. During the past century much theological labour was focused on this dogma by leading theologians - theological research that unfortunately was hardly ever noticed by preachers and lay people. In this article special attention is paid to the theology of Oepke Noordmans in this regard. God's chosen people are the pick of the bunch (1 Cor. 1:26-29), because the doctrine of election rather proclaims that God is not fastidious at all. His choice is motivated merely by our misery. It is argued that dogmatics and ethics (respectively: faith and life) are intimately related. The transition from doctrine to ethics that occurs at the beginning of Romans 12 is taken as point of departure. The well-known Reformed adage, soli Deo gloria is identified as the very heart of both Reformed dogmatics and ethics.
\end{abstract}

\section{Opsomming}

\section{Uitverkiesing en etiek}

Die leerstuk van die uitverkiesing is van fundamentele belang vir die gereformeerde tradisie. Gedurende die vorige eeu het leidende teoloë baie aandag bestee aan hierdie dogma, wat ongelukkig dikwels onopgemerk verbygegaan het by predikers en gewone lidmate. In besonder word in hierdie artikel gefokus op die teologie van Oepke Noordmans. Die uitverkorenes is dit nie op grond van hulle uitstaande kwaliteite nie, want juis die uitverkiesing leer ons dat God hoegenaamd nie kieskeurig is nie. Sy keuse word gemotiveer deur ons ellende. Dogmatiek en etiek (respektiewelik: geloof en lewe) is ten nouste verbonde. Die oorgang van leer na lewe wat ons aantref aan die begin van Romeine 12, word geneem as uitgangspunt. Die bekende gereformeerde adagium, soli Deo gloria, word identifiseer as die hart van sowel die gereformeerde dogmatiek as etiek. 


\section{Inleiding}

Die jubilaris en die skrywer van hierdie artikel is lidmate van verskillende kerke, maar albei behoort deur geboorte en by voorkeur tot die gereformeerde tradisie. Laasgenoemde word meer as enige ander vertakking binne die Christelike kerk sterk geassosieer met die leer van die uitverkiesing. Weliswaar geld dit meer van die Gereformeerde Kerke as van die NG Kerk wat tot gevolg het dat die spiritualiteit van die twee kerke aanmerklik verskil. Vanuit die Gereformeerde Kerke is die NG Kerk meermale van Metodisme beskuldig. Omgekeerd word soms bedenkinge van fatalisme en determinisme gefluister. Indien die moontlikheid bestaan dat in albei tipes verdenking 'n element van waarheid skuil, sou 'n herbesinning van hierdie leerstuk, wat ons gemeenskaplike kerkvader Calvyn as die hart van die kerk bestempel het, sinvol en selfs noodsaaklik wees.

Die kombinasie van begrippe in ons titel gaan uit van die oortuiging dat leer en lewe nie los staan van mekaar nie, maar 'n ondeelbare eenheid vorm. Dit blyk by voorbeeld uit die feit dat die mees algemene beswaar teen die leer van die uitverkiesing eties van aard is. Dit sou 'n Godsbeeld en mensbeeld impliseer met potensieel funeste gevolge vir die etiek. God sou op 'n willekeurige, dit wil sê 'n moreel onverantwoordbare wyse, sommige mense lukraak verkies tot sy kinders en ander verwerp, of wat op min of meer op dieselfde neerkom - oorlaat aan hulle lot. Wanneer God vereenselwig word met die lot, bly dit 'n vraag of die begrippe "sonde" en "skuld" nie eerder vervang moet word met woorde soos "toeval" en "tragies" nie. Dat dit gevolge het vir die etiek, is sonder meer duidelik.

In gereformeerde kringe is die afgelope eeu besonder diep nagedink oor hierdie sentrale leerstuk van die kerk sonder dat die nuwere insigte goed deurgedring het tot die geloofsbewussyn van die deursneelidmaat. In hierdie verband is die werk van G.C. Berkouwer, De verkiezing Gods (1955) ${ }^{1}$ asook die eksegese van H.N. Ridderbos van Romeine 9-11 in sy Aan de Romeinen (1959)2, van groot betekenis. Maar reeds in 1921 skryf Oepke Noordmans (1921:124-134) sy beroemde artikel "Predestinatie", wat volgens Berkouwer (1989:267) in sy laaste boek Zoeken en vinden, groot invloed uitgeoefen het op die teologie van die twintigste eeu en deur hom as "opzienbarend" bestempel word. 3

1 Sien ook Berkouwer (1974 hoofstuk 4: "Om het hart der kerk").

2 Sien ook Ridderbos (1966:380-403).

3 Reeds dertig jaar tevore skryf Noordmans, pas aangeland op universiteit, aan sy vader 'n diepgrawende brief oor die uitverkiesing (Theron, 2000: 21). 
Die woord "etiek" in die titel van hierdie artikel moet nie verstaan word in die sin van die wetenskap van die etiese (respektiewelik: sedelike) nie. Soos dit soms selfs in vakliteratuur gebeur (Rothuizen, 1973:14), word die begrip voorwetenskaplik gebruik en derhalwe nie duidelik onderskei van ander begrippe soos sedelikheid en moraal nie.

\section{Leer en lewe}

Die speurverhaalskrywer Dorothy Sayers (s.j.:15) is van mening dat een van die hoofoorsake vir verveling in die kerk te wyte is aan die verwaarlosing van die sogenaamde "vervelige" dogma. Sy noem die dogma 'n skrikaanjaende drama waarin God tegelyk die slagoffer en die held is. Haar siening staan radikaal teenoor die populêre opinie wat weerspieël word in die bekende grappie waarvolgens die opvallendste verskil tussen die leer van die kerk en die leer waarvan skoene gemaak word, daarin bestaan dat van dié twee eersgenoemde die droogste is.

Selfs in teologiese kringe word soms beweer dat die leer van minder belang is as die lewe. Nie wat jy dink nie, maar wat jy doen, is deurslaggewend. Daarmee saam gaan die oortuiging dat die leer verdeel, maar moraliteit verenig. Kennis van die Christelike leer is immers nie nodig om mense die regte morele keuses te laat maak nie. Die eise van die wet staan immers ook in die harte van die heidene geskrywe (Rom. 2:15). In 'n wêreld wat dreig om as gevolg van uiteenlopende geloofsoortuigings in duie te stort, kan dit polities verstandig wees om dogmatiese verskille liewer links te laat lê en alle nadruk te laat val op gemeenskaplike etiese oortuigings.

Noordmans vertel iewers dat in vroeër eeue die gebruik bestaan het om wanneer die predikant 'n sekere punt in sy preek bereik het, hy met 'n stentorstem sou uitroep: Toepassing! Dit was die teken dat diegene wat intussen ingesluimer het, moes wakker word. Die explicatio was afgehandel; dit het tyd geword vir die applicatio. Die dominee was klaar met die leer; nou sou dit gaan om die lewe. Die preek was klaar met God se wese en werke; wat ons prakties moet doen in die alledaagse praktyk, was nou die punt op die agenda.

Ook in Paulus se briewe vind 'n mens meermale so 'n oorgang van die leer na die lewe. 'n Besonder treffende voorbeeld tref ons aan na afloop van die eerste elf hoofstukke van die Brief aan die Romeine. Vir elf hoofstukke was Paulus besig met wat God vir ons gedoen het. Dit het gegaan oor sonde en versoening, oor die regverdiging van die goddelose, oor die rol wat die wet in die proses gespeel het, en oor die uitverkiesing. Oor laasgenoemde het hy juis in die vorige drie hoofstukke (Rom. 9-11) gehandel. Klaarblyklik vorm dit die klimaks van die vooraf- 
gaande, meer leerstellige gedeelte. Teen die einde van hoofstuk 11 gaan die leer oor in 'n lied op "die diepte van die rykdom en wysheid en kennis van God!" (vs. 33).

Anders as baie gelowiges in die eeue na hom vind Paulus die uitverkiesing nóg vervelig, nóg verskriklik, maar veeleer verruklik. Teen die einde van hoofstuk 11 is hy nie vreesbevange nie, maar vol vreugde. Hy sug nie; hy sing. Die slotwoorde van sy lied lui: "Uit Hom en deur Hom en tot Hom is alle dinge. Aan Hom behoort die heerlikheid tot in ewigheid! Amen" (Rom. 11:36).

Klaarblyklik het hy nou 'n spesifieke punt in sy "preek" bereik. Dit blyk duidelik uit die begin van hoofstuk 12: "En nou doen ek 'n beroep op julle ..." Die New International Version vertaal nog duideliker: "Therefore, I urge you ..." Daar is 'n duidelike samehang tussen wat Paulus pas gesê het, en wat hy op die punt staan om te sê. Aan die begin van hoofstuk 12 kry 'n mens byna die indruk dat hy sy vinger in die lug steek en uitroep: Toepassing!. Wie onder die besinning oor die uitverkiesing aan die slaap geraak het, moet nou ontwaak. So 'n siening berus egter op 'n ernstige misverstand omdat dit die noue verband tussen leer en lewe in die denke van Paulus misken. Wanneer mense die verkeerde konklusie uit sy leer trek vir die praktiese lewe, antwoord Paulus met 'n verontwaardige (Rom. 6:2): Beslis nie! Paulus sal op dieselfde wyse reageer indien jy leer en lewe van mekaar isoleer. Wie onder sy uitleg van die uitverkiesing weggedommel het, mag wat volg, totaal verkeerd verstaan. Wat volg, is juis die gevolgtrekking uit die voorafgaande. Wat ons dink én doen, berus geheel en al op wat God vir ons gedoen het. Wie dit nie in gedagte hou nie, verval maklik in moralisme, 'n gevaar waaraan die gereformeerde (puriteinse) moraal nie altyd ontsnap het nie. Evangelieprediking ontaard dan in moraalprediking.

In de kerk brengt het de mensen onfeilbaar in het slaap. Boetprediken kan zo onbarmhartig zijn. Het is: de stof van het mensenleven tussen duim en wijsvinger nemen, zoals de lakenkoper het weefsel. Wie het doet, vergeet meestal, dat hij van dezelfde lap is gescheurd. De zedenprediker zoekt kwaliteit; hij wordt verbitterd, omdat hij het niet aantreft (Noordmans, 1946:37).

Daarteenoor lui Romeine 12:1: "En nou doen ek 'n beroep op julle op grond van die groot ontferming van God ..." Laasgenoemde is in ' $n$ neutedop die tema van die vorige drie (respektiewelik 11) hoofstukke. Opvallend hoedat die woord "ontferm" soos 'n refrein weerklink deur die verse voorafgaande aan die doksologie - Romeine 11: 30, 31, 32: "God het Hom oor julle (heidene) ontferm ... Maar dit het gebeur sodat hulle self (die Jode) nou ook ontferming kan vind ... God het almal (Jood en 
heiden) aan die ongehoorsaamheid oorgegee, sodat Hy Hom oor almal (Jood en heiden) kan ontferm." God se ontferming is die eintlike tema van die uitverkiesing. Verre van droog is die dogma van die kerk volgens Noordmans (1934:181) 'n uitbeelding van die Heilige Gees op heterdaad betrap, besig om 'n gemoed te troos. Dit is juis hierdie ontferming as inhoud van die uitverkiesing, wat in die res van Romeine die grond en fondament is waarop Paulus hom beroep vir die etiese voorskrifte wat volg.

\section{Die wet maak die sonde wakker}

Ten einde Hom oor almal te kan ontferm, het die wet wat God aan sy uitverkore volk gegee het, 'n besondere rol gespeel. Volgens Romeine 11:32 het God "almal (Jood en heiden) aan die ongehoorsaamheid oorgegee, sodat Hy Hom oor almal (Jood en heiden) kan ontferm". Dit klop met hoofstuk 3 waar Paulus betoog dat die Jode nie beter is as die ander nie "want ons het al bewys dat Jode en nie-Jode almal in die mag van die sonde is" (vs. 9). Die Jode het wel die wet gehad, maar dit het die sonde nie minder nie, maar meer gemaak. Romeine 5:20: "Die wet het bygekom om die oortredinge nog meer te maak; en hoe meer die sonde geword het, hoe oorvloediger het die genade geword."

Oor hierdie funksie van die wet om sonde te vermeerder, handel Paulus in die besonder in Romeine 7, 'n hoofstuk wat belangrik is vir sy betoog in Romeine 9-11. Anders as wat dikwels gedink word, is Paulus in hierdie hoofstuk nie besig met sy outobiografie nie. Die "ek" waarvan hier sprake is, moet retories verstaan word as "n mens", respektiewelik die mensheid. Meer in die besonder gaan dit om die geskiedenis van Israel wat binne die breë raamwerk van die wêreldgeskiedenis geplaas word. "Israël staat ... in het volle licht en daarachter in vagere omtrekken de hele mensheid" (Noordmans, 1934b:104). Hierdie relasie tussen mensheid en Israel, heidendom en Jodendom, Adam en Christus, is van deurslaggewende betekenis vir die hele brief.

Dit blyk onder andere uit die sinspelings in Romeine 7 op die eerste hoofstukke van Genesis. Soos die vakeksegete kan aantoon, is daar in hierdie hoofstuk allerlei verskuilde verwysings na Adam (en Eva) asook na Kain, wat kenmerkend was van die Jodendom en die vroeë kerk. ${ }^{4}$ In 'n ou Joodse geskrif staan die uitspraak: "Elkeen van ons was die Adam van sy eie siel." In Romeine 7 is Israel Adam, en die sonde die slang wat die wet gebruik om die mens te mislei en sodoende in die dood te stort.

$4 \quad$ Wright (1992: Hoofstuk 12) het nie minder nie as nege argumente om aan te toon dat Kain op ' $n$ verskuilde wyse figureer in Romeine 7 . Kain is onder andere beeld van die "wandelende Jood" en die dubbelslagtige mens (Rom. 7:19). 
Daarom verwys Paulus (Rom. 7:7) spesifiek na die 10de gebod (Eks. 20: 17): Jy mag nie begeer nie. Dit herinner aan die verbod om te eet van die verbode vrug wat Adam en Eva juis daarom tog so begeerlik gevind het.

Die effek van die wet wat aan Israel gegee is, was dieselfde as die verbod in die tuin van Eden: dit het allerlei begeertes gewek en sodoende die verborge sonde na buite gelok. Waar die mens met die heilige wet van God in aanraking kom, is die sondeval telkens die gevolg. Ons leef dus nie maar net in 'n gevalle wêreld nie, maar veeleer in 'n vallende wêreld waarin die wet die sonde vermeerder.

In Israël is de zondeval veel concreter, meer historisch, duidelijker afgebeeld dan in het paradijsverhaal. Paulus zegt het zelf. De zonde en de dood hebben geheerst van Adam tot Christus, maar de overvloed der genade heeft toch haar eigenlijk tegenbeeld in het overvloeien der zonde in Israël door de wet" (Noordmans, 1934b: 103). 5

In Romeine 7 word die sondeval vir ons geteken as:

... nu niet meer zo, dat men in de verzoeking kan komen de verzoeking voor een mythe te houden, en ook niet meer in de concrete historische vorm van Israëls geschiedenis, waardoor men haar voor afgelopen kon houden, maar als een gebeurtenis in de kerk onder het kruis (Noordmans, 1934b:106).

Dit klop met Romeine 3:20: "Daarom sal geen mens op grond van wetsonderhouding vrygespreek word nie; inteendeel, deur die wet leer 'n mens wat sonde is". Die bedoeling is dat die wet die mens in die sonde stort, en sodoende die sonde vermeerder. Dat die wet die mens uit die sondeverslawing kan verlos, is daarom ondenkbaar. Deur die gebod kry die sonde juis ' $n$ vastrapplek en gebruik sodoende die wet om my te mislei en te dood (Rom. 7:11), want die sonde kry sy krag uit die wet van God (1 Kor. 15:56). Vandaar Paulus se klag teen die einde van hoofstuk 7: "Ek ellendige mens! Wie sal my van hierdie doodsbestaan verlos?" Daarop is net een moontlike antwoord: "Aan God die dank! Hy doen dit deur Jesus Christus ons Here." En Paulus onderstreep dit in hoofstuk 8:3: "Wat die wet nie by magte was om te doen nie, omdat dit weens ons sondige vlees te swak was, dit het God gedoen."

Nie dat die wet self sonde is nie (Rom. 7:12), maar soos met al God se goeie gawes, gebruik die sonde die gawes teen die Gewer. Geïsoleer

5 Ook Noordmans, 1934:113: "Israel laat ons de zondeval zien - ik zei het reeds - veel reëler dan Genesis 3." 
van die Gewer word die gawe 'n demoniese historiese mag wat die sluimerende sonde wakkermaak en ons al hoe dieper in die verderf stort. Die gawe neem die plek in van die Gewer, met die gevolg dat die tiende gebod, soos al die gebooie, eintlik waarsku teen die oortreding van die eerste (as jy wil: eintlike) gebod (Eks. 20:3): "Jy mag naas my My geen ander gode hê nie". Slegte begeertes en gierigheid word derhalwe in Kolossense 3:5 as afgodery bestempel (Wright, 1983:163). Verre daarvan dat die Jode as die uitverkore ontvangers van die wet van God dus enige morele voorsprong het bo die heidene, het juis die (goeie) wet van God (Rom. 11:32) almal (Jood en heiden) aan die ongehoorsaamheid oorgegee.

In 'n gewaande skuldlose wêreld wat nie kennis dra van sonde nie, kon die Lam van God wat die sonde van die wêreld wegdra, nie kom nie. Daarom moes die wet bykom "sodat die sonde in sy ware aard as sonde bekend sou word en dit deur die gebod sou blyk hoe skrikwekkend die sonde werklik is" (Rom. 7:13). Pas dán kan die grootheid van God se genade in Christus geopenbaar word. Soos wat die wet die sonde uit sy skuilplek te voorskyn roep en dit sodoende aan die kaak stel, roep die nood van die wêreld die Seun van God uit die hemel te voorskyn om die sonde te oorwin aan die vloekhout. Tot hierdie taak wat gelyktydig skrikwekkend en wonderbaar is, het God Israel verkies as sy kinders en aan hulle die wet gegee. In Christus wat tot sonde vir ons gemaak is (2 Kor. 5:21), is Moses en Adam, Jood en heiden, saamgevoeg (vgl. Ef. $1: 10)$ en sodoende "almal aan die ongehoorsaamheid oorgegee, sodat Hy Hom oor almal kan ontferm" (Rom. 11:32) sodat die hele Israel (Jood en heiden) gered kan word (Rom. 11:26). Op Golgota gaan die vallende wêreld van die eerste Adam ten gronde om in Christus vir ewig begrawe te word. 6 Nou blyk duidelik dat dit net so moontlik is vir die ou Adam om homself te red, as wat dit is om self uit die dood op te staan. Die verkorenes is diegene wat geroep is om in Christus, en daarom saam met Christus die Uitverkorene Kneg (Matt. 12:18 - ou vertaling), gekruisig te word. Met die offer van die Messias van Israel wat die vervulling en derhalwe die einde is van die wet, word die doel van God met sy volk bereik (Rom. 10:4).

Ten spyte van hulle ontrou; meer nog: deur middel van hulle ontrou, het God sy verkiesingsdoel bereik. Die geskiedenis van die uitverkore volk wat kulmineer in die vonnis van die Kruis as (doel)einde van die geskiedenis van Israel (en die wet), maak duidelik dat God die goddelose vryspreek. "Hy is vanweë ons oortredings oorgelewer en $\mathrm{Hy}$ is opgewek sodat ons vrygespreek kan word" (Rom. 4: 25). Die verbond 
met Israel bereik sy klimaks, waardeur die genade van God aan Jood en heiden geopenbaar kan word (Wright, 1992). Geen wonder nie dat Paulus teen die einde van sy behandeling van die uitverkiesing die leer laat oorgaan in ' $n$ lied. Die beloftes aan Abraham wat die heidene ingesluit het, is in Christus Ja (2 Kor. 1:20). Dit is dan ook begryplik dat Kaylor (1988) die woorde "sonder onderskeid" (Rom. 3:22) as die sleutel tot die hele brief beskou (vgl. ook Bassler, 1982:156). God trek immers niemand voor nie (Rom. 2:11). Almal het gesondig en word sonder dat hulle dit verdien, op grond van sy genade vrygespreek vanweë die verlossing deur Jesus Christus (Rom. 3:23 e.v., vergelyk Rom. 1:16).

\section{Meer as menslike moraal}

Indien die lewe nie meer is as moraal nie, word die bestaan dor en droog en word ons bedreig deur geestelike versmoring (Noordmans, 1946:37). Die evangelie daarenteen is soos ' $n$ bundel sonstrale wat plotseling deur ' $n$ dakopening in 'n stowwerige skuur val en die bedompige ruimte omtower tot 'n profesie van 'n hoëre wêreld (Noordmans, 1935:79).

Volgens Noordmans (1921:128) impliseer die uitverkiesing 'n verruiming van ons sedelike besef op 'n wyse wat ons morele maatstawwe totaal in verwarring bring. In hierdie leer het ons werklik met die "Umwertung aller Werte" te make, en dit skyn daarom vyandig te staan teenoor alle sedelikheid en etiek. Gods genade stel ons bekrompe menslike moraliteit onder kritiek sonder om die regmatigheid daarvan te ontken (Noordmans, 1935:79 e.v). Sonder moraal kan geen gemeenskap immers oorlewe nie. Oppervlakkig beskou, vind 'n mens baie van die sedelike voorskrifte in Paulus se briewe ook in buite-Bybelse bronne. Die groot verskil is egter geleë in die vreugde van die evangelie wat sy lig laat skyn oor ons moraliteit (Noordmans, 1946:36). Sonder daardie lig is moraliteit en immoraliteit ewe ver van die Vaderhuis. Aan die kruis "is de Zoon in het verre land gereisd, in het land van het moraal, zoals de verloren zoon in de gelijkenis in het land der immoraliteit. En Hij is er even ver van de Vader als de zoon in de gelijkenis. Hoor zijn klacht aan het kruis" (Noordmans, 1946:42).

Noordmans (1921:132) toon aan hoedat ons aan ons etiese oortuigings probeer vasklou in die wyse waarop die eerste van die saligsprekings dikwels verklaar word. Gewoonlik word gesê dat Matteus se weergawe 'n versagting is van dié van Lukas, omdat laasgenoemde die materieel armes saligspreek. Daarmee gaan gepaard die oortuiging dat Matteus se "armes van gees" dui op 'n sedelik positiewe kwaliteit. Maar Noordmans wonder of dit nie dalk andersom is en Lukas 'n versagting is van Matteus nie. Sou dit dalk kon wees dat die "armes van gees" dui op sedelike armoede en Lukas dit tot sosiale armoede wil versag? Wanneer die 
sedelik armes salig gespreek word, word ons bloot menslike moraal daarmee verdoem en moet dit derhalwe in opstand kom. Hier is dan ook die diepste rede te vinde vir die weersin wat die sedelikheidsapostels van alle eeue koester teen die leer van die uitverkiesing.

Dit blyk nog nie duidelik wanneer ons van die uitverkiesing 'n bloot logiese probleem maak nie, soos dikwels in die verlede gebeur het in die debat tussen supra- en infralapsarisme. Die kontrovers maak 'n uiters abstrakte indruk en neig daartoe om die uitverkiesing los van Christus, die Lam van God wat die sonde van die wêreld wegdra, te verstaan. Veral die supralapsarisme wat die uitverkiesing in die raad van God vooraf laat gaan aan die sondeval, is daarom so onbevredigend. Daarteenoor kies Noordmans met oortuiging vir die infralapsarisme, waarin juis die uitverkiesing se ware aard van genade ten volle na vore kom. "De predestinatie gaat niet logisch aan goed en kwaad vooraf, maar gaat zedelik boven goed en kwaad uit" (Noordmans, 1921:131). Ten diepste is ons aanstoot aan die evangelie van Gods genade dan ook nie logies van aard nie, maar eerder eties. Gods genade transendeer die bloot menslik-sedelike sfeer en plaas in die proses ons menslike moraal onder kritiek. Terselfdertyd behels dit 'n wonderlike troos. "Zoveel weten we dan toch, dat wanneer naar onze zedelijke berekeningen de wereld verloren is, zij daarom toch niet verloren is" (Noordmans, 1921:132).

In hierdie verband dink Noordmans aan Nietzsche se bekende jenseits von Gut und Böse. Hy vind daarin 'n gelykenis van die uitverkiesing omdat albei staan teenoor die opperheerskappy van menslike reg en moraal. Tog is daar 'n hemelsbreë verskil: "De christelijke predestinatiegedachte kweek ootmoed; de 'Uebermensch' breekt uit in hoogmoed" (Noordmans, 1921:126). Terwyl eersgenoemde die onderskeid tussen goed en kwaad uitwis en daarom onsedelik is, is die genadige verkiesing van God bo-sedelik sodat die bloot sedelike nie daar kan bykom nie. Soos God se gedagtes hoër is as ons gedagtes, gaan ook sy sedelikheid ons sedelikheid te bowe.

Een meer omvattend, meer doordringend oordeel zou de zedelike factoren in de predestinatie ontdekken. De schijnbare willekeur zou zich voor een intellect van hoger orde in schone ethische tekening projecteren (Noordmans, 1921:127).

Hierdie aard van die uitverkiesing as meer as menslike moraal, met die daarmee gepaardgaande evangeliese vreugde, kom besonder duidelik na vore in die gelykenis van die arbeiders wat op verskillende ure gehuur is. Hierdie gelykenis eindig met dié woorde (Matt. 20:16): "So sal die 
laastes eerste wees, en die eerstes laaste."7 Dit word gesê na aanleiding van die aanstoot wat geneem word omdat die eienaar van die wingerd aan die laastes net soveel gegee het as die eerstes. Teenoor die eerstes het die heer weliswaar nie oneties opgetree nie, maar hom gehou by die billikheid van die kontrakreg. Waarteen die sedelikheidsapostels dit egter het, is sy optrede wat bo reg en billikheid uitgaan teenoor die laastes in die gelykenis. Daarop sê die eienaar (Matt. 20:14 e.v.): "Vat jou geld en gaan huis toe. Ek wil aan hierdie laaste een net soveel gee as vir jou. Mag ek nie met my geld maak wat ek wil nie? Of is jy afgunstig omdat ek goed is?"

Die goedheid van God is die eintlike aanstoot van die verkiesing. Asof $\mathrm{Hy} \mathrm{Hom} \mathrm{nie} \mathrm{mag} \mathrm{ontferm} \mathrm{oor} \mathrm{wie} \mathrm{Hy} \mathrm{wil} \mathrm{en} \mathrm{barmhartig} \mathrm{mag} \mathrm{wees} \mathrm{oor} \mathrm{wie}$ Hy wil nie (vgl. Rom. 9:15 e.v.). Die uitverkiesing beteken nie God se genade is beperk nie; nee, dit is so ruim dat diegene wat nie in genade geïnteresseerd is nie, aanstoot neem. God se genade is so ruim dat dit die blindes en bedelaars, die sondaars en tollenaars, ja al die onaansienlikes wat in die evangelies om die Gekruisigde saamdrom, akkommodeer. Dit is so ruim dat jy jouself moet uitsluit as jy nie van die geselskap hou nie.

Pragtig dié kommentaar van Noordmans (1935:81):

Als de dag om is, de arbeid gedaan, de zon gedaald, dan komt het feest der hemelhoge goedheid nog. Dan heeft God tijd voor zijn laaste werk aan de 'laatsten'. Dan zijn de anderen naar huis; zij die ... zoals de ouderwetse Statenvertaling het zo krachtig zegt: hun loon weg hebben. Staat het mij niet vrij met het mijne te doen wat ik wil? Zo luidt het dan. Dan is God helemaal vrij om God te zijn, om goed te zijn. De loontrekkers zijn weg; de billijkheid is uit wandelen gezonden; de deftige rechtmatigheid op pensioen gesteld. Alles verandert nu. De denarius is geen loon meer, maar een cadeau. De afrekening is geen betaling meer maar een uur van geschenken. De ontvangst is geen verdienste meer, maar genade. En de wijngaard is tot paradijs geworden.

\section{God is nie kieskeurig is nie}

Die leer van die genadige verkiesing en die leer van die regverdiging van die goddelose deur die geloof alleen, is onlosmaaklik verbonde. Calvyn wat gewoonlik met die leer van die uitverkiesing geassosieer word, kan terselfdertyd die regverdiging bestempel as die vernaamste artikel waarop die godsdiens rus (Inst. $3,11,1)$. Die twee artikels verduidelik me-

Ander lesings voeg nog by: "want baie is geroep, maar min uitverkies" (vgl. Matt. 22:14). 
kaar oor en weer. Die regverdiging deur die geloof maak duidelik dat die verkiesing nie verstaan moet word in onpersoonlike kousale kategorieë wat met 'n fatalistiese determinisme gepaard gaan nie. Die predestinasie is die keersy van die Triniteit en moet daarom ook trinitaries, en nie deterministies nie, verstaan word (Noordmans, 1934a: 243). Die Gees oorrompel nie met geweld nie, maar oorreed met die blye boodskap. "God is de Koning der eeuwen, maar meer nog die der ogenblikken. Zijn besluit is van eeuwigheid, maar Hy neemt het op het laaste moment" (Noordmans, 1949:110). Die onweerstaanbaarheid van die genade moet daarom nie verwar word met 'n onpersoonlike krag soos byvoorbeeld die wet van swaartekrag wat kousaal werk nie. Veeleer moet ons dink aan twee geliefdes wat mekaar "onweerstaanbaar" vind. Die liefde is nie 'n mindere mag as die wet van swaartekrag nie, maar dit is wel andersoortig. Dieselfde geld van Johannes 6:44: "Niemand kan na My toe kom as die Vader wat My gestuur het, hom nie na My toe trek nie ...". Ook hierdie "trekkrag" van die evangelie moet verstaan word in die sin waarin die een geliefde die ander "aantreklik" vind. Dit impliseer geen onpersoonlike dwang nie, maar skep juis die allergrootste vryheid. In hierdie persoonlike (teenoor onpersoonlik-algemene) aspek van die uitverkiesing is die soetheid (Noordmans, 1955a:379) van die uitverkiesing geleë.

Terselfdertyd moet geloof nie sinergisties geïnterpreteer word as menslike aanvulling, met of sonder Gods hulp, van die heil in Christus nie. Die werk van die Heilige Gees is immers nie 'n tweede genade nie, maar bestaan daarin dat Hy ons leer leef uit God se eerste genade. Indien dit nie goed begryp word nie, word die leer van die regverdiging van die goddelose (Rom. 4:5) vervang met die leer van die regverdiging van die gelowige. Dan verskuif ons vertroue van die genade van God na ons geloof in die genade van God, waardeur dit juis ophou geloof te wees. Luther (Hof, 1972:19) het hierdie gevaar baie goed besef soos blyk uit sy krasse uitspraak: in fide accepta niti - hoc est fornicari (om op die ontvange geloof te vertrou is hoerery). Weliswaar is geloof 'n gawe van God, maar dit geld ook van goeie werke as vrug van die Gees. Om jou byvoorbeeld op grond van jou geloof te laat doop, bestempel Luther as afgodery, want jy vertrou dan op 'n gawe wat God jou gegee het en nie op God se Woord alleen nie (Luther, 1964:165). Immers "Es ist gar viel ein ander Ding, den Glauben haben und sich auf den Glauben verlassen" (Luther, 1964:164). Luther se aksent op die geloof alléén moet derhalwe nie verstaan word om 'n besondere aksent op die geloof as menslike faktor te plaas nie, maar juis om alle menslike aandeel uit te 
skakel (Noordmans, 1934a:307). Of soos Noordmans dit elders stel (Noordmans, 1946a:81):

Het sola fide is niet ontstaan door een deling van geloof en werken. Dan was geloof ook nog een soort werk en deed nu alleen, wat het vroeger met de werken samen deed. Maar neen, het is slechts geloof. Het is heel iets anders dan werken. Uit een zeker oogpunt gezien veel minder. Het is niet de helft, maar evenmin een ander onderdeel, hoe klein ook. Het is de grens van alle werk, waar werken ophoudt. Het is de limiet van alle steeds kleiner wordende delen, die het voor zich zou kunnen opeisen bij een deling.

Die sola fide vorm derhalwe geen bedreiging vir die sola gratia en solus Christus nie, maar onderstreep juis die eenheid van die leer van die regverdiging van die goddelose en die leer van Gods genadige verkiesing. Geloof alleen korrespondeer met redding van die goddeloses alleen en beteken daarom dieselfde as God alleen.

Indien menslike meriete en moraal geen rol speel in die verkiesing nie, kom dit vir ons voor of dit neerkom op niks anders nie as Goddelike willekeur. Wat Calvyn bestempel as die hart van die kerk, klink daarom vir baie mense uiters harteloos. 'n Teks soos Romeine 9:15 e.v. wat die barmhartigheid van God beklemtoon, maak meermale juis 'n uiters onbarmhartige indruk:

Vir Moses het God gesê: Ek sal barmhartig wees oor wie Ek barmhartig wil wees, en my ontferm oor wie Ek my wil ontferm. Dit hang dus nie af van 'n mens se wil en strewe nie, maar van God wat barmhartig is.

Dit wil dus voorkom of ons gedwing word tot 'n keuse tussen Goddelike willekeur en menslike aandeel (sinergisme).

Die uitverkiesing beteken egter nie dat God willekeurig is nie, maar veeleer dat Hy hoegenaamd nie kieskeurig is nie. "How odd of God to choose the Jews", lui 'n bekende spotspreuk waardeur die hart van die evangelie en daarmee ook die uitverkiesing, aangetas word. In Deuteronomium 7:7 lees ons reeds: "Die Here het jou nie liefgekry en gekies omdat jy groter was as die ander volke nie, jy was die kleinste van almal." Vir Joodse selfverheffing is daar weliswaar geen grond nie, maar dit geld eweneens vir heiden-Christelike arrogansie. Verre daarvandaan dat Paulus die vader is van anti-Semitisme, veroordeel hy dit ten sterkste. Om Jood te wees beskou hy in baie opsigte as voordelig (Rom. 3:1 e.v.). "Hulle is tog Israeliete; vir hulle het God as sy kinders aangeneem en in sy heerlikheid was Hy by hulle; met hulle het Hy die verbonde gesluit en aan hulle die wet van Moses gegee, asook die tempeldiens en die beloftes" (Rom. 9:4). Per slot van sake is Israel die 
"natuurlike takke" (Rom. 11: 21) terwyl die heidenchristene, soos 'n wilde olyf "teen sy natuur" op die mak olyf ingeënt is (Rom. 11:17, 24). Juis in die uitverkiesing blyk dat dit nie afhang van wat 'n mens doen nie, maar van Hom wat jou roep (Rom. 9:13). Net so min geskied dit op grond van wie jy is - dit wil sê dit hang nie af van die bloed in jou are nie. Jakob en Esau was kinders van Isak en nog boonop 'n tweeling (Rom. 9:10). Abraham het sowel by Hagar as Sara 'n seun gehad, maar net die een was kind van die belofte (Gal. 4:23).

Paulus se groot droefheid en voordurende hartseer oor sy volksgenote (Rom. 9:1-3) is dat hulle nie die genadige uitverkiesing van God soos dit tot uitdrukking kom in die verbond met hulle aartsvader Abraham, verstaan het nie (Rom. 4). Dit is juis as onbesnedene - dit wil sê as deel van die mensheid buite Israel - dat hy die belofte ontvang het dat hy die vader van die gelowiges sou wees, dit wil sê van diegene wat nie op wetsonderhouding staatmaak nie, maar glo in Hom wat die goddelose vryspreek (Rom. 4:5). Die "wet van die geloof" wat staan teenoor "die wet van werke" sluit alle roem van watter aard ook al uit (Rom. 3:27), omdat eersgenoemde rus op niks anders nie as God se genadige en barmhartige belofte alleen.

Die woorde in Romeine 9:15 waarvolgens God barmhartig sal wees oor wie Hy wil en Hom ontferm oor wie Hy wil, moet daarom nie verwar word met willekeur nie. Eerder moet ons weereens dink aan die gelykenis van die arbeiders wat op verskillende ure gehuur is en die eerste arbeiders wat beswaar maak teen die eienaar se genadige optrede teenoor die laaste huurlinge. Die feit dat God niemand voortrek nie (Rom. 2:11) maak op die eerste arbeiders die indruk dat God 'n onaanvaarbare, vreemde voorkeur het vir die laastes. Dit is die eintlike aanstoot van die evangelie van die uitverkiesing: God kies slegs mense wat dit nie verdien nie, naamlik goddeloses en ellendiges. In die gelykenis van die verlore Seun is daar twee seuns, maar die verlore seun is die verkore seun. Volgens Noordmans stel die jongste seun deur sy ellende die oudste seun in die skadu. Dieselfde geld van Lasarus en die ryk man. Dit klop met Paulus se woorde in 1 Korintiërs 1:26 e.v.:

Dink net broeders aan wat julle was toe julle geroep is. Volgens die opvatting van mense was daar nie baie geleerdes of baie invloedrykes of baie mense van aansien onder julle nie. En tog, wat vir die wêreld swak is, het God uitverkies om die sterkes te beskaam, en wat niks is nie, het God uitverkies om wat iets is tot niet te maak. Voor God het geen mens dus iets om op te roem nie. Aan God is dit te danke dat julle met Christus Jesus verenig is. Hy het vir ons geword die wysheid wat van God kom: die vryspraak, die heiliging, die verlossing. Daarom soos geskrywe staan: Die wat roem, moet in die Here roem. 


\section{Uitverkies tot offer}

"En nou ..." vervolg Paulus nadat hy teen die einde van Romeine 11 in 'n doksologie uitgebreek het oor die ontferming van God soos dit na vore kom in die uitverkiesing, "... nou doen ek 'n beroep op julle, broers, op grond van die groot ontferming van God: Gee julleself aan God as lewende en heilige offers wat vir Hom aanneemlik is. Dit is die wesentlike van die godsdiens wat julle moet beoefen" (Rom. 12:1). Die betekenis van 'n lewe van offerande wat rus op die merietelose, genadige uitverkiesing konkreet tot in die praktiese politiek, toon Paulus dan aan in die res van Romeine (Meeks, 1987).

Om die lewe van die gelowige as 'n offer te tipeer, is propvol gevare. Jüngel wys op die neiging van Westerse moraliste om hulle te bedien van offerterminologie en in die proses ' $n$ teologiese kategorie eties te interpreteer. "Modern humanity sacrifices - or rather an appeal is made to modern humanity to sacrifice - for the sake of humanity. Humanity offers sacrifices to itself" (Jüngel, 1995:164; sien ook Theron, 1999:336). 'n Lewe van offerande is egter niks minder nie as 'n daaglikse sterf en opstaan met Christus. Dit is geen nabootsing van die offer van Christus nie, maar 'n navolging van Christus wat rus in sy volbragte offer.

Noordmans (1955a:312) wys daarop dat die Westerse wêreld deur die eeue 'n groot ophef maak van diens (staatsdiens, militêre diens, erediens, ridderlike diens) terwyl dit terselfdertyd so afkerig is van die dienskneggestalte. In ons diens soek ons meermale ons eie gedaante en heerlikheid wat ver verwyder is van 'n offer aan God.

Paulus se etiek is 'n poging om die aard van die Christelike offer te verduidelik. Hy doen sy bes om hierdie offer skerp te onderskei van die kultiese offers van die Ou Testament. Soos wat Christus die einde is van die wet (Rom. 10: 4), is hy ook die einde van die tempel. 8 In die boek Handelinge lees ons hoedat die Heilige Gees Paulus gebruik om in te gryp in die Joodse wet, en Stefanus om dieselfde te doen teenoor die tempel. Terwyl ons vertroud is met die teenstelling genade en wet, vind Noordmans dit jammer dat ons nie 'n parallelle begrippepaar ken om die teenstelling met die tempel (respektiewelik die kultiese offerdiens) aan te dui nie. Ons kan die uitdrukking in Romeine 12:1 ("die wesentlike van die godsdiens") ook vertaal as "geestelike godsdiens", maar gestel ons sou ten opsigte van die eerste teenstelling (genade en wet) "genade" vervang met "geestelike wet", sou dit die teenstelling minder treffend maak. 
Noordmans is veral uiters bedug teen die vertaling van latreia in Romeine 12:1 as "erediens". Die gevaar bestaan dat ons sal meen dat Paulus die Joodse tempeldiens net maar vervang het met 'n Christelike kultiese erediens. Volgens Paulus vind die eintlike liturgie nie kulties plaas in 'n kerk nie, maar sedelik in die daaglikse samelewing. Daarom het Noordmans ernstige kritiek teen die "liturgiese beweging" soos dit na vore kom in sy eie kerk in aansluiting by die Anglikanisme met hulle imponerende liturgie. Soos Jesus die straat van die openbare lewe deel met die blinde bedelaars, die tollenaars (publicani) en die "straatvroue", so vind ook die eintlike liturgie van die gelowiges plaas in die lewe (Noordmans, 1955d:299). Daarmee word die noodsaaklikheid van 'n (sobere) vorm van kerklike liturgie nie ontken nie, want ons bid en wag nog op die wederkoms. Derhalwe is 'n sekere terughouding in die openbare lewe onontbeerlik (Noordmans, 1955d:298). Maar terughouding moet nie verwar word met geestelike emigrasie nie. Liturgie in die lewe ${ }^{9}$ bestaan volgens Augustinus se verduideliking in De civitate Dei daarin dat ons vir Hom bloedige slagoffers bring wanneer ons ten bloede toe stry vir sy Waarheid, terwyl ons vir Hom reukoffers brand wanneer ons voor sy aangesig in vrome en heilige liefde ontvlam (Noordmans, 1955:416). Die liefde is per slot van sake die volle uitvoering van die wet (Rom. 13:10).

Soos die dogmatiek eindig met eer aan God (Rom. 11), so begin ook die Christelike etiek met soli Deo gloria. "Of julle eet en of julle drink of wat julle ook al doen, doen alles tot eer van God" (1 Kor. 10:31). So 'n lewe van offer aan God is geen sware las nie, maar 'n loflied.

My wens aan die jubilaris is dat die waarheid van Romeine 14:7 e.v., wat ons terugvind in Sondag 1 van die Heidelbergse Kategismus, hom ook vorentoe sal vergesel:

Niemand van ons leef tog vir homself nie, en niemand sterf vir homself nie. As ons lewe, leef ons tot eer van die Here; en as ons sterwe, sterf ons tot eer van die Here. Of ons dan lewe en of ons sterwe, ons behoort aan die Here.

\section{Bibliografie}

BASSLER, J.M. 1982. Divine Impartiality. Paul and a theological axiom. SBL Dissertation Series 59. Harvard : Scholars Press. (Doctoral thesis.)

BERKOUWER, G.C. 1955. De verkiezing Gods. Kampen : Kok.

9 Vergelyk die proefskrif van I.J. van der Merwe (1999 - veral hoofstuk 3: "Noordmans: Liturgie as offer in die lewe"). 
BERKOUWER, G.C. 1974. Een halve eeuw theologie. Motieven en stromingen van 1920 tot heden. Kampen : Kok.

BERKOUWER, G.C. 1989. Zoeken en vinden. Kampen : Kok.

HOF, O. 1972. Luthers Unterscheidung zwischen dem Glauben und der Reflexion auf den Glauben. Kerygma und Dogma,18:294-324.

Institusie van Calvyn (1559)

kyk Sizoo (1956)

JÜNGEL, E. 1995. Theological Essays 2. Edingburgh : Clark.

KAYLOR, R.D. 1988. Paul's covenant community: Jew and Gentile in Romans. Atlanta : John Knox.

LUTHER, M. 1964. Von der Wiedertaufe an zwei Pfarrherrn. Luthers Werke 26. Kritische Gesamtausgabe. Weimar : Weimar Ausgabe.

MEEKS, W.A. 1987. Judgment and the Brother: Romans 14:1-15:13. (In Hawthorne, G.F. with Betz, O., ed. Tradition and Interpretation in the New Testament. Grand Rapids : Eerdmans. p. 290-300.)

NOORDMANS, O. 1921. Predestinatie, V W 2, 124-134. Kampen : Kok.

NOORDMANS, O. 1934. Het kerkelijk dogma, V W 2, 170-195. Kampen : Kok.

NOORDMANS, O. 1934a. Herschepping, V W 2, 214-322. Kampen : Kok.

NOORDMANS, O. 1934b. Psychologie en Evangelie, V W 2, 98-118. Kampen : Kok.

NOORDMANS, O. 1935. Dingen die verborgen waren, V W 2, 57-83. Kampen : Kok.

NOORDMANS, O. 1946. Moraal en Evangelie, V W 8, 34-43. Kampen : Kok.

NOORDMANS, O. 1946a. Sola fide, V W 8, 80-83. Kampen : Kok.

NOORDMANS, O. 1949. Kohlbrugge. Festpredigten, V W 3, 293-327. Kampen : Kok.

NOORDMANS, O. 1949a. Epifanie, V W 8 108-110. Kampen : Kok.

NOORDMANS, O. 1955. Verkiezing, V W 8, 378-380. Kampen : Kok.

NOORDMANS, O. 1955a. Idee en werklijkheid, V W 8, 311-313. Kampen : Kok.

NOORDMANS, O. 1955b. De Wet, V W 8, 412-414. Kampen : Kok.

NOORDMANS, O. 1955c. De Tempel, V W 8, 414-417. Kampen : Kok.

NOORDMANS, O. 1955d. Jezus op straat, V W 8, 298-300. Kampen : Kok.

RIDDERBOS, H. 1966. Paulus. Ontwerp van zijn theologie. Kampen : Kok.

RIDDERBOS, H. 1959. Aan de Romeinen. Kampen : Kok.

ROTHUIZEN, G. Th. 1973. Wat is ethiek? Kampen : Kok.

SAYERS, D. s.j. Het grootste drama dat ooit werd opgevoerd. Amsterdam : Vrij Nederland.

SIZOO, A. 1956. Institutie of onderwijsing in de Christelijke godsdienst. (Uit die Latyn vertaal.) Derde druk. Delft : Meinema.

THERON, P.F. 1999. Blooming or bleeding? The "South African dream" in the light of eschatological peace. Ned. Geref. Teologiese Tydskrif, xxx(3,4):324-337, Sept./ Des.

THERON, P.F. 2000. Noordmans as briefskrywer. Kerk en theologie, 51(1):16-23, Jan.

VAN DER MERWE, I.J. 1999. Liturgie en lewe. 'n Sistematies-Teologiese ondersoek. Stellenbosch : US. (D.Th-proefskrif.)

WA $=$ Weimar Ausgabe kyk Luther. 1964.

WRIGHT, N.T. 1992. The climax of the covenant. Christ and the law in Pauline theology. Minneapolis : Fortress.

WRIGHT, C.J.H. 1983. An eye for an eye. The place of Old Testament ethics today, Ilinois : Intervarsity Press. 


\section{Kernbegrippe:}

dogmatiek en etiek

Noordmans, $\mathrm{O}$.

sonde en wet

uitverkiesing en regverdiging

\section{Key concepts:}

dogmatics and ethics

election and justification

Noordmans, $\mathrm{O}$.

sin and law 